\title{
O PERSONAL GROWTH AS A STRONG ELEMENT IN THE MOTIVATION OF AUSTRALIAN UNIVERSITY STUDENTS TO LEARN GERMAN
}

\begin{abstract}
Gabriele Schmidt Australian National University
Gabriele.Schmidt@anu.edu.au

Gabriele Schmidt is a lecturer in German Studies at the Australian National University $(A N U)$ in Canberra. Her research interests include language teaching and learning in higher education, language learning motivation, and curriculum development.
\end{abstract}

\begin{abstract}
For the last ten years, language learning motivation research has focussed on how learners see knowledge of a language as part of their identity. This article presents the findings of a qualitative interview study that investigated whether personal growth is also a strong element in the motivation of Australian university students to learn German. After first outlining the theoretical framework in which the study is situated and describing the research design and method, the article will present the main findings and argue that personal growth as well as a desire to broaden one's horizons are strong motives for Australian students of German. The article concludes by discussing the findings and their implications.
\end{abstract}

KEY WORDS: language learning motivation, Ideal L2 Self, university students, German, qualitative research

\section{INTRODUCTION}

People who have grown up in an English-speaking country often feel "blessed" that they have learnt a global language as their first language. However, some point to the disadvantages caused by the dominance of English, Wierzbicka (2014) for example, warns of the danger of becoming 'conceptually imprisoned in English', and it remains difficult to promote the learning of foreign languages in countries with English as the predominant language (cf. Busse \& Walter, 2013, p. 435). Despite having developed the first comprehensive National Policy on Languages (Lo Bianco, 1987) in the English-speaking world (Ingram, 2002, p. 11), which listed one foreign language for all as one of its objectives, Australia appears to be particularly resistant to foreign language learning. Figures that show, for example, less than $15 \%$ of Year 12 students in Australia learn a language other than English at school (Curnow, 2010, p. 38) support Clyne's (2007, p. 12) assessment that Australia has 'a complacently monolingual mindset'.

The reasons for this ongoing reluctance to learn another language are complex and go beyond superficial attitudes that "the rest of the world speaks English anyway". They include Australia's geographical isolation, questions of national identity, and economic priorities. 
Liddicoat and Scarino (2010, p. 2) argue that since the 1970s a change in government often also meant a change in language policy and priority languages depending on the respective government's engagement with, or disengagement from, Asia. A situation that, they conclude, has led to a 'weakening of the position of languages in schools'.

Universities, on the other hand, have in recent years recorded a sound interest in students learning a language, particularly European languages at the beginners' level (Nettelbeck et al., 2007, p. 12). One likely reason for this development is the broadening of arts and other degrees that several universities, e.g. the University of Melbourne and the University of Western Australia, have undertaken and which has made it easier for students to integrate language courses into their degrees. Pauwels (2002, p. 17) argues that this opening-up of university language programs is a result of government reforms introduced in the mid-1990s which, due to a new funding model for universities, required language programs to increase their income. While this explains the institutional priority, the question remains as to what value do students see in learning a language as part of their degree?

This article aims to answer this question by presenting the findings of a qualitative study that analyses the motivation of Australian undergraduates to study German. While a first analysis of the data revealed various reasons for learning German, e.g. an interest in German-speaking culture or a wish to travel to Europe, it also indicated that personal growth appears to be a strong element in students' motivation to learn German at university (cf. Schmidt, 2014). This article provides a deeper analysis of these personal reasons for learning German as expressed by the participants during interviews. The article first outlines the theoretical framework in which the study is situated before describing the research design and method. The central part will then present the main findings and argue that personal growth is a strong motive for Australian students to learn German, and the article concludes by discussing the findings and their implications.

\section{THEORETICAL BACKGROUND}

In the last 25 years, two comprehensive studies (Ammon, 1991; Schmidt, 2011) have investigated the reasons why Australian university students learn German. Ammon's and Schmidt's analyses focus on what Dörnyei and Ottó (1998, pp. 47-48) describe as the 'preactional phase', i.e. on the 'motivational influences' that initially lead students to choose German as part of their degree. The findings of both studies point to a diversity of motives with Schmidt (2011, p. 110) identifying three main motivational factors. The first and most dominant motivational factor relates to 'a general interest in the German language and culture paired with a joy and an appreciation of learning languages'. The second factor corresponds to 'the wish to communicate in a German-speaking country while working, studying or travelling'. The third factor reflects 'German being considered as an important (business) language that could bring professional advantages'. 
Schmidt's (2011) finding of three motivational factors reveals a more complex picture than Gardner's traditional dichotomy of integrative and instrumental motivation which has dominated research into language learning motivation for the last fifty years (see for example Gardner, 1985; Gardner \& Lambert, 1972). Critique of Gardner's model includes the question whether the concept of integrative motivation, i.e. the goal to become a member of the target language community, can be applied to languages that have become global languages, such as English, without a specific culture attached to them (Dörnyei, 2009, pp. 23-24; Ushioda \& Dörnyei, 2009, pp. 2-3). Dörnyei (2010, pp. 78-79) has therefore shifted the integrative motivation from the learner's goal to become like someone from the target language community, to the learner's goal to develop themselves closer towards their own 'ideal self'. If the 'ideal self', i.e. the vision learners have of themselves, includes proficiency in another language Dörnyei (2005, p. 102) considers this Ideal L2 Self as similar to Gardner's traditional concept of Integrativeness 'in that L2 speakers are the closest parallels to the idealized L2-speaking self'. Motivation is created by the learner's 'desire to reduce the discrepancy' between the actual and ideal selves (Dörnyei, 2005, p. 105). While Dörnyei (2005, pp. 105-106) sees his Motivational L2 Self System as closely related to Gardner's concept of Integrativeness, Gardner (2010) has rejected this comparison by arguing that Dörnyei's 'L2 self is a cognitive model while that of integrative motivation is an affective one' (pp. 222-226).

Dörnyei (2005, pp. 118-119) raises the possibility that the L2 Motivational Self System might apply more to the learning of world languages such as English. It seems likely that the concept also applies to languages that are learnt geographically remote from the target language community. Learners of world languages, such as English, and languages that are learnt geographically remote from the target language community, have in common the difficulty to have a well-founded knowledge about the target culture and its people.

The questionnaire used in Schmidt's (2011) study contained 26 questions listed on a Likertscale, but only one question related to language learning as part of someone's personal development. Although this reason 'Learning German broadens my world view' received the third largest level of agreement, a single score does not allow the drawing of any definitive conclusions. The new qualitative study presented in this article therefore aimed to expand the 2011 study by investigating whether concepts such as the Ideal L2 Self are also evident in the motivation of Australian university students to learn German.

\section{METHOD}

Ammon's (1991) and Schmidt's (2011) studies both stand in the tradition of quantitative research that has dominated research into language learning motivation since Gardner and Lambert's (1959) first publication. Since that publication, many studies have used questionnaires and scales to collect data about learners' motives and attitudes and have 
applied statistical measures when analysing the data. The ongoing popularity of questionnaires can be explained by the fact that they can be distributed to a large number of participants, the data can be analysed with computer software, and the results can be generalised. However, as Dörnyei (2007, p. 115) emphasises, the "necessary simplicity of the questions $[\ldots]$ usually provide a rather "thin" description of the target phenomena'. In particular with the current focus on the Ideal L2 Self, it does not surprise that in recent years qualitative methods such as learner biographies (e.g. Riemer, 2011) or interviews have been used increasingly to broaden the scope of the quantitative tradition (cf. Dörnyei \& Ushioda, 2011, p. 237; Ushioda \& Dörnyei, 2012, pp. 401-402).

The abovementioned questionnaire survey (Schmidt, 2011) was conducted in 2005 and received responses from 520 Australian university students learning German. To broaden the understanding of the findings, 16 interviews with university students of German were conducted in 2013. It was expected that qualitative data would provide a deeper 'insider perspective' (cf. Dörnyei, 2007, p. 38) into the subject matter. Hence, the qualitative study presented in this article falls into what Ivankova and Creswell (2009) call the 'explanatory design' category, i.e. 'qualitative findings are used to help explain, refine, clarify, or extend quantitative results' (p. 139).

\section{PARTICIPANTS}

All 16 participants were undergraduates and enrolled in various disciplines, ranging from science, business, arts, and law, to sports studies. Only one student enrolled in a Bachelor of International Studies had language study mandated by his degree. The others studied German as an elective or as part of a Diploma in Languages. Twelve students attended the beginners' level and four the intermediate level. Only one participant was an international student and four had German heritage. Ten participants were male, six female. All interviewees named English as their first language. Information about each participant can be found in Table 1 below.

Table 1. Participants in the interview study

\begin{tabular}{|c|c|c|c|c|c|c|}
\hline & Name* & Gender & Age & Level & Degree & $\begin{array}{l}\text { German } \\
\text { Heritage }\end{array}$ \\
\hline 1 & Tom & male & 28 & beginners & Science & no \\
\hline 2 & Melanie & female & 18 & beginners & Arts & maybe \\
\hline 3 & Daniel & male & 21 & beginners & $\begin{array}{l}\text { Management/ } \\
\text { Psychology }\end{array}$ & no \\
\hline 4 & Elisabeth & female & 21 & intermediate & Maths & no \\
\hline 5 & James & male & 21 & beginners & Commerce & no \\
\hline
\end{tabular}




\begin{tabular}{|c|c|c|c|c|c|c|}
\hline 6 & Anna & female & 21 & beginners & $\begin{array}{l}\text { Languages/ } \\
\text { Linguistics }\end{array}$ & yes \\
\hline 7 & Ben** & male & 22 & beginners & Sports Studies & no \\
\hline 8 & Alexandra & female & 23 & beginners & Science & no \\
\hline 9 & Joshua & male & 22 & beginners & Science & yes \\
\hline 10 & Sam & male & 21 & beginners & $\begin{array}{l}\text { International } \\
\text { Relations/Economics }\end{array}$ & no \\
\hline 11 & John & male & 23 & beginners & Science & no \\
\hline 12 & Bianca & female & 18 & intermediate & Arts & no \\
\hline 13 & Matthew & male & 18 & beginners & Arts/Science & no \\
\hline 14 & Sarah & female & 18 & intermediate & Arts/Laws & no \\
\hline 15 & Tim & male & 20 & beginners & Arts & yes \\
\hline 16 & Patrick & male & 18 & intermediate & International Studies*** & no \\
\hline
\end{tabular}

All 16 students were enrolled at the University of Queensland (UQ), a prestigious university that belongs to Australia's Group of Eight universities. The University of Queensland was chosen because in 2005 the largest number of participants in the questionnaire survey came from UQ. Since the analysis of the 2005 data did not reveal major significant differences between the ten universities it can be assumed that the responses given by the interviewees are not specific for UQ only. All 16 students self-selected to be interviewed after information about the study was circulated in class. With regard to the results it is important to keep in mind that participants who self-select most likely fall into the group of 'committed language students' (Martín \& Jansen, 2012, p. 176), i.e. students who are highly motivated.

\section{DATA COLLECTION}

The interviews were conducted in the fourth and fifth week of the first semester in 2013 , a good time to investigate the initial motivation that had brought students in the language classroom. They were conducted on-campus, lasted for about 30 minutes and were audiorecorded. The set-up of the interviews followed common interview techniques such as outlined by Kvale (2007). The semi-structured interviews began with an open question about the respondent's reasons for learning German which then led to follow-up questions or 
questions along the interview guide (see Appendix A). Some of the questions were replicated from Busse and Williams' (2010) study of English university students learning German. Their questions were based in part on Ushioda's (1996) study. The interviews were conducted in English.

\section{DATA ANALYSIS}

All interviews were transcribed verbatim by the author. In addition, noticeable non-verbal features such as pauses, cut-offs, laughter, emphasis and sound-stretching were marked in the transcripts using transcription symbols as used in conversation analysis (cf. Hutchby \& Wooffitt, 1998, pp. vi-vii). Appendix B lists the symbols used in the transcripts.

The data analysis followed a mixture of grounded theory coding methods (see for example Charmaz, 2006, pp. 42-71) and general content analysis principles applied in qualitative research (see for example O'Leary, 2010, pp. 256-277). After an initial (nearly) line-by-line coding the data was reduced to common themes expressing the participants' motivation to learn German. For managing and analysing the data the qualitative data analysis software MAXQDA (version 11) was used.

\section{ETHICAL CONSIDERATIONS}

The study received human ethics approval from the author's home university as well as from the University of Queensland where the interviews were conducted. To assure participants' anonymity their real names were replaced with pseudonyms in the transcripts.

\section{RESULTS}

As analysed in Schmidt (2014) the overall results of the interview study not only confirm the three motivational factors identified in the 2005 questionnaire survey, but also provide a greater insight into the students' perspectives on them. The content analysis of the 16 interviews has revealed new motives such as: perceiving the knowledge of German (or a second language in general) as part of one's identity (Ideal L2 Self), a strong affinity with European culture with several respondents expressing the wish to move to Europe once they have finished university; and considering a proficiency in German as an advantageous add-on to the students' primary degree subjects. The strong evidence of personal growth as a key element in the motivation of the 16 interviewees was rather unexpected and therefore the following data analysis will focus on those motives that are closely related to the learner's identity and personal development. 


\section{AUSTRALIA'S GEOGRAPHICAL ISOLATION AND ITS IMPACT ON ATTITUDES TOWARDS LEARNING A SECOND LANGUAGE}

It has been widely acknowledged that 'the tyranny of distance' (Blainey, 1966) has shaped not only Australia's history but also its identity and the identity of its people. Hence, this first section explores identity related motives in a wider sense before the following sections focus on the individual learner.

The interview data suggests that on the one hand, Australia's remoteness leads to a curiosity towards other cultures and languages as expressed by Daniel in the following interview extract:

I don't see those European countries being quite similar to Australia so I think yeah if it was I don't think I would be as interested in them (...) in learning German and about the culture $[. .$.$] it's interesting it's intriguing that they are totally different so (.) that's$ yeah that's part of the (.) motivation behind me (.) wanting to learn know more. [Daniel Interview 3/Section 28-30]

Another interviewee, Alexandra, goes a step further by underlining Australia's necessity to interact with other cultures due to its geographical isolation:

when you look at a map Australia is kind of quite isolated I mean it's fairly close to Southeast Asia but when you compare it with the countries of Europe for example it's completely isolated and so I think it's quite important to ahm to cultivate that friendship with other countries from around the world ahm so that Australian people then have the same opportunities. [Alexandra 8/32]

On the other hand, Australia's isolation is also perceived as a hurdle with regard to learning other languages. The following extract is by the same student (Daniel) who earlier on referred to the otherness of European cultures as a motivating factor to learn more about these cultures and hence reflects the conflict Australian students are facing when deciding whether to learn a second language or not:

you kind of have to make a ahm conscious decision to want to learn another language when you live in a place like Australia because (.) because otherwise there is no real incentive to if you're never going to leave you can stay here your whole life and work and live comfortably but never have to speak any other words than English. [Daniel 3/48]

This comment strongly suggests that the motivation of Australian students to learn a modern European language goes beyond pragmatic reasons such as wanting to communicate with people from neighbouring countries. While Australia's geographical distance to Europe seems to create a certain level of curiosity towards other cultures, Daniel's remark, that for Australians learning another language is a 'conscious decision', indicates that the motivation has deeper roots. 


\section{PROFICIENCY IN ANOTHER LANGUAGE AS PART OF STUDENTS' SELF-IMAGE (IDEAL L2 SELF)}

Nearly all students stated that learning another language was something they had 'always wanted' to do. A closer examination of the verbs students used to express their reasons to learn German reveals that most verbs express a personal desire (verbs in italic):

I really liked being able to express myself in another language. [Sarah 14/4]

I'm just fascinated with other languages. [Sam 10/22]

I always wanted to learn German. [Joshua 9/2]

I have always loved languages. [Alexandra 8/6]

it would be nice to know another language. [Melanie 2/22]

This internal desire is important in light of Dörnyei's Ideal L2 Self (see part 2) as opposed to the Ought-to L2 Self, the latter referring to 'attributes one ought to possess to meet expectations' from others (Dörnyei \& Ushioda, 2011, p. 86).

That students regard their knowledge of German as part of who they are becomes evident in the following comment by Sarah:

I always bring it up when people say like name three things about yourself I can say I can sort of speak German or like yeah it is quite important. [Sarah 14/14]

Similarly, Tom links his aspired knowledge of German to his personal development:

It's just kind of a personal growth kind of thing (.) [...] so that maybe (.) I'm a more interesting person at the end of the day hehe you know maybe that little quirk of mine is oh I am and I speak German. [Tom 1/22]

Since Dörnyei's Ideal L2 Self relates to the self-image the learner has of him or herself in the future, Tom's statement is the strongest evidence of the Ideal L2 Self. He refers to his vision of himself in the future ('at the end of the day') and how he imagines that the person he will be ('I am') will be inseparable from his ability to speak German ('and I speak German'): 'I am and I speak German'. Moreover, he repeats several times during the interview that learning German 'it's more just for me' [1/28] and that 'it's just something personal' [1/56].

Tom was not the only student who referred to language learning as part of his personal development. Patrick [16/30] also emphasises that 'it's a personal development thing' while Matthew [13/18] stresses that 'there's more to it' than gaining career benefits from learning German. Matthew argues that the huge effort it takes to learn a language could not be sustained without the feeling that one benefits at a personal level. 
Examples of how students feel they benefit from knowing another language include:

it's something I'm interested in (.) so I suppose that kind of (.) makes me feel better about myself. [Patrick 16/30]

you \$feel like a more intelligent person\$ if you can express yourself in (.) more than your own language. [Bianca 12/26]

it personally makes me feel more full [...] maybe (.) I'm a more interesting person. [Tom 1/22]

being able to learn or speak another language fluently does impress Europeans $[\ldots]$ and even people in Australia go oh you- (.) speak a different language. [Daniel 3/10]

The responses above demonstrate that the roots of motivation to learn a second language lie deep inside the learner. Students consider the ability to know another language as an integral part of who they are or who they want to be in the future (Ideal L2 Self). They feel that learning another language assists them in growing as a person.

\section{PERCEIVING LANGUAGE LEARNING AS BROADENING ONE'S HORIZONS}

Returning to the first, and broader aspect of identity-related motives, i.e. Australia's geographical isolation, it is unsurprising that most students stated that learning another language enables them to 'look to the world' and to overcome being 'very narrow-minded':

learning another language I think shows a certain determination in yourself to not just (.) be very narrow-minded or just just focused on you know where you're living right now it ah (.) shows you've broadened your horizon a little bit you (.) you want to look to the world you're a bit more worldly you look to the outside. [Daniel 3/10]

Specifically, students feel enriched by receiving an additional perspective on the world:

I think that would kind of just enhance your knowledge of the language and kind of also give you a bit of like multiperspectivism in terms of your own knowledge about the world. [Patrick 16/24]

the German culture and the Australian culture are two completely different if you've got an understanding of how German culture might see you get two ah perspectives on one issue. [Sam 10/104]

you broaden your opportunities and you broaden your knowledge and the way you think about the world. [Melanie 2/54]

While 'broadening one's knowledge' sounds rather abstract, some students linked this broader knowledge to concrete gains such as having a better understanding of other people, being more aware of world issues and having more empathy for people: 
it allows (.) you to understand the just the various ways of different ways of communicating ahm like and (.) it gives you a greater (.) capacity to understand I guess ahm a little more sort of (..) empathy ahm for people. [Tim 15/36]

learning another language and then you learn about the other culture definitely makes you more aware of (.) well problems and world issues and things like that. [Sarah $14 / 28]$

The following two statements by Sarah and Bianca summarise all of the above comments by emphasising that knowing another language 'opens doors' to the outside as well as to the inside ('mind'):

I really liked being able to express myself in another language I think it opens doors a lot. [Sarah 14/4]

learning a language sort of opens that part of your mind ahm to be able to do all sorts of other things. [Bianca 12/26]

While the last two statements both refer explicitly to language learning as opening doors and one's mind, the other comments indirectly contain the same idea by underlining that learning another language opens the view 'to the outside', opens new 'perspectives' and opens 'opportunities'. This sense of language learning as a means to opening doors at various levels is in line with Wierzbicka's (2014) earlier mentioned concerns that speakers of English are in danger of becoming 'imprisoned in English' (p. 193). One of the disadvantages faced by monolingual speakers of English she lists is that 'there is a wall between ourselves and other people'. The statements above show how the interviewees feel that knowledge of another language breaks down this wall.

\section{DISCUSSION}

The aim of this study was to investigate whether identity-related motives are evident in the motivation of Australian university students learning German. The data analysis has revealed that first, students consider being able to speak German as part of the vision they have of themselves (Ideal L2 Self). Patrick [16/30], for example, referred to language learning as 'a personal development thing' while Tom [1/56] stressed several times that 'it's just something personal'. Second, students see learning another language as an important exercise to broaden their horizons. Daniel [3/10], for example, stated that it enabled him to 'look to the outside'. It is at this deeper level of motivation where the qualitative data of this study has provided greater insights into students' deliberations when compared with former quantitative studies. The overall tone of the 16 interviews reflects highly motivated language learners who appear to be very aware that learning another language involves more than acquiring a set of linguistic skills. While this enthusiasm for learning another language is 
very positive, it must be recognised that the participants of this study had all volunteered to be interviewed and were most likely very committed and highly motivated language students to begin with.

The close relationship between language learning and the learner's identity has been acknowledged for a long time. Charles the Great, for example, is often quoted as having said 'to have another language is to possess a second soul'. More recently, Dörnyei (2005) has argued that 'a foreign language is more than a mere communication code that can be learnt similarly to other academic subjects; instead; it is also part of the individual's personal core, involved in most mental activities and forming an important part of one's identity' (p. 93). Bianca [12/26] makes in her comment that 'learning a language sort of opens that part of your mind to be able to do all sorts of other things' an explicit reference to the 'mind'. This is a good example of how learners link language learning to what Dörnyei calls 'mental activities'.

Most of the 16 participants in the study referred at some stage during the interview to language learning as something they were doing for themselves, arguing, as Matthew [13/18] did, that otherwise it would be hard to sustain the effort given the time it takes to learn a language. This observation by Matthew that pure career-related, i.e. instrumental reasons would not be enough to sustain his motivation over time supports Gardner's (2002, p. 167) claim that an integrative motive may last longer than an instrumental motive. Gardner (2002, p. 163) also points to the 'long-term commitment' it takes to learn another language.

The interview data has also revealed that students consider language learning as an important means to broaden their horizons and to broaden 'the way you think about the world' [Melanie 2/54]. This is an important result given that some have argued that knowledge of another language has become a commodity that adds value to other qualifications (see for example Kramsch, 2014, pp. 301-302) but is not any longer considered as having merits in its own right. While the overall results of the study (Schmidt, 2014, pp. 34-35) show that students feel that learning German adds value to their degree, it is encouraging that they see beyond these pragmatic benefits and are aware that through language learning they gain new perspectives. Statements such as you get 'multiperspectivism in terms of your own knowledge about the world' [Patrick 16/24], you get 'a little more [...] empathy for people' [Tim 15/36] and that it 'makes you aware of problems and world issues' [Sarah 14/28] support Byram's (2008, pp. 228-229) claim that language education plays an important role in developing students' intercultural competence and in contributing to the overall objective of 'intercultural citizenship'. Byram (2008) sees intercultural competence as being able 'to critically analyse one's own values, beliefs and behaviours'. To be able to critically analyse one's own perspective requires a second point of reference, i.e. a second perspective which language learners acquire through learning a new language as summarised by Sam [10/104]: 'the German culture and the Australian culture are two completely different if you've got an understanding of how German culture might see you get two perspectives on one issue'. 
Many graduates will work in an intercultural environment and the opening-up of language programs (see part 1) will assist students in developing an intercultural awareness.

The bigger challenge, however, is the issue of how university language and culture courses can integrate the personal growth dimension into their curricula given that courses are designed for groups and not for individuals. While the study presented in this article did not have the objective to develop teaching approaches the results suggest that first, language and culture courses should be designed around topics that are relevant and related to students' personal experiences and memories thus allowing reflection. Second, course content should present new ideas to students which sometimes might challenge their existing views.

In summary, the study has shown that Australian students learning German at university consider language learning as an important part of their personal development. While one could label this dimension as inward-looking the study has also revealed that students feel that learning another language enables them to 'look to the outside' [Daniel 3/10]. Kramsch (2014, p. 309) emphasises that these two dimensions are not contradicting but rather complementing each other by concluding that for 'learners developing their own voice increasingly means developing an ear for the voices of others'. While Kramsch further explains that this is a 'lifelong, educational goal', future research should investigate how university language and culture courses can assist students on their way to achieve this goal.

\section{REFERENCES}

Ammon, U. (1991). Studienmotive und Deutschenbild australischer Deutschstudenten und-studentinnen. Stuttgart: Franz Steiner Verlag.

Blainey, G. (1966). The tyranny of distance: How distance shaped Australia's history. Melbourne: Sun Books.

Busse, V., \& Walter, C. (2013). Foreign language learning motivation in higher education: A longitudinal study of motivational changes and their causes. Modern Language Journal, 97(2), 435-456.

Busse, V., \& Williams, M. (2010). Why German? Motivation of students studying German at English universities. Language Learning Journal, 38(1), 67-85.

Byram, M. (2008). From foreign language education to education for intercultural citizenship. Clevedon: Multilingual Matters.

Charmaz, K. (2006). Constructing grounded theory: A practical guide through qualitative analysis. London: Sage.

Clyne, M. (2007). Are we making a difference? On the social responsibility and impact of the linguist/applied linguist in Australia. Australian Review of Applied Linguistics, 30(1), 3.1-3.14.

Curnow, T. (2010). Participation in languages education in Australian schools. In A. Liddicoat \& A. Scarino (Eds.), Languages in Australian education: Problems, prospects and future directions (pp. 25-40). Newcastle upon Tyne: Cambridge Scholars. 
Dörnyei, Z. (2005). The psychology of the language learner: Individual differences in second language acquisition. Mahwah, NJ: Lawrence Erlbaum.

Dörnyei, Z. (2007). Research methods in Applied Linguistics. Oxford: Oxford University Press.

Dörnyei, Z. (2009). The L2 Motivational Self System. In Z. Dörnyei \& E. Ushioda (Eds.), Motivation, language identity and the L2 self (pp. 9-42). Bristol: Multilingual Matters.

Dörnyei, Z. (2010). Researching motivation: From integrativeness to the ideal L2 self. In S. Hunston, \& D. Oakey (Eds.). Introducing applied linguistics: concepts and skills (pp. 74-83). London: Routledge.

Dörnyei, Z., \& Ottó, I. (1998). Motivation in action: A process model of L2 motivation. Working Papers in Applied Linguistics 4 (pp. 43-69). London: Thames Valley University.

Dörnyei, Z., \& Ushioda, E. (2011). Teaching and researching motivation ( $2^{\text {nd }}$ ed.). Harlow: Longman.

Gardner, R. C. (1985). Social psychology and second language learning: The role of attitudes and motivation. London: Edward Arnold.

Gardner, R. C. (2002). Social psychological perspectives in second language acquisition. In R. B. Kaplan (Ed.), The Oxford handbook of applied linguistics (pp. 160-169). Oxford: Oxford University Press.

Gardner, R. C. (2010). Motivation and second language acquisition: The socio-educational model. New York: Peter Lang.

Gardner, R. C., \& Lambert, W. E. (1959). Motivational variables in second-language acquisition. Canadian Journal of Psychology, 13(4), 266-272.

Gardner, R. C., \& Lambert, W. E. (1972). Attitudes and motivation in second-language teaching. Rowley: Newbury House.

Hutchby, I., \& Wooffitt, R. (1998). Conversation analysis. Cambridge: Polity.

Ingram, D. E. (2002, December 7). Language and culture policy in multicultural Australia. Invited paper presented at the Annual Convention of the Society for Oceanian Education Studies, Akita University, Japan.

Ivankova, N., \& Creswell, J. W. (2009). Mixed methods. In J. Heigham \& R. A. Croker (Eds.), Qualitative research in Applied Linguistics (pp. 135-161). Basingstoke, Hampshire; New York: Palgrave Macmillan.

Kramsch, C. (2014). Teaching foreign languages in an era of globalisation: Introduction. Modern Language Journal, 98(1), 296-311.

Kvale, S. (2007). Doing interviews. London: Sage.

Liddicoat, A., \& Scarino, A. (2010). Languages in Australian education: an introduction. In A. Liddicoat \& A. Scarino (Eds.), Languages in Australian education: Problems, prospects and future directions (pp. 1-8). Newcastle upon Tyne: Cambridge Scholars.

Lo Bianco, J. (1987). National policy on languages. Canberra: Australian Government Publishing Service.

Martín, D., \& Jansen, L. (2012). Identifying possible causes for high and low retention rates in language and culture programs at the Australian National University: a characterization of three groups of students crucial for understanding student attrition. In J. Hajek, C. Nettelbeck, \& A. Woods (Eds.), The next step: Introducing the Languages and Cultures Network for Australian universities (pp. 175-219). Melbourne: Languages \& Cultures Network for Australian Universities. 
Nettelbeck, C., Byron, J., Clyne, M., Hajek, J., Lo Bianco, J., \& McLaren, A. (2007). Beginners' LOTE in Australian universities: An audit survey and analysis. Canberra: Australian Academy of the Humanities.

O’Leary, Z. (2010). The essential guide to doing your research project. London: Sage.

Pauwels, A. (2002). Languages in the university sector at the beginning of the third millenium. BABEL, $37(2), 16-20$.

Riemer, C. (2011). Warum Deutsch(noch) gelernt wird - Motivationsforschung und Deutsch als Fremdsprache. In H. Barkowski, S. Demmig, H. Funk, \& U. Würz (Eds.), Deutsch bewegt: Entwicklungen in der Auslandsgermanistik und Deutsch als Fremd- und Zweitsprache (pp. 327-340). Baltmannsweiler: Schneider Verlag.

Schmidt, G. (2011). Motives for studying German in Australia. Frankfurt am Main: Peter Lang.

Schmidt, G. (2014). There's more to it: A qualitatitive study into the motivation of Australian university students to learn German. German as a foreign language, 1, 21-44.

Ushioda, E. (1996). Language learners' motivational thinking: a qualitative study. Doctoral Thesis. Dublin: Trinity College.

Ushioda, E., \& Dörnyei, Z. (2009). Motivation, language identities and the L2 self: A theoretical overview. In Z. Dörnyei \& E. Ushioda (Eds.), Motivation, language identity and the L2 self (pp. 1-8). Bristol: Multilingual Matters.

Ushioda, E., \& Dörnyei, Z. (2012). Motivation. In S. M. Gass \& A. Mackey (Eds.), The Routledge handbook of second language acquisition (pp. 396-409). New York: Routledge.

Wierzbicka, A. (2014). Imprisoned in English. Oxford, New York: Oxford University Press. 


\section{APPENDIX A: INTERVIEW GUIDE}

i. Could you just talk me through your reasons for studying German?

ii. Do you have any other reasons for studying German?

iii. Did you learn German already at school?

iv. If yes, could you please tell me a bit about your experience and whether it has influenced your decision to continue at uni?

v. Could you explain a bit what you hope to gain from studying German at university level?

vi. Are your reasons for studying German linked to any long-term plans that you might have?

vii. Did job considerations play a role for you?

viii. Do you envisage using German in the future?

ix. Have you ever visited a German-speaking country?

x. If yes, could you tell me a bit what you did over there and how your experience was?

xi. A former survey revealed that Australian university students learning German are interested in German-speaking people and their culture. Could you please talk me through what comes to your mind when you think of German-speaking people and their culture?

xii. In your German classes, what would you like to learn about German-speaking people and their culture?

xiii. This might be a bit difficult, but do you have a picture or a sort of vision of yourself with regard to German?

xiv. Australia's neighbouring countries are mainly Asian and the Government has recently released a white paper on Australia in the Asian Century. Where do you see the role of European languages such as German in Australia?

xv. The former survey also revealed that Australian university students learning German believe that learning German broadens their world view. Do you agree?

xvi. If yes, in what way?

xvii. How would you describe the relationship between language and culture?

xviii. Is there anything else you wish to add? 


\section{APPENDIX B: TRANSCRIPTION SYMBOLS}

(.)

$-$

emphasis

hehe

\$laughter\$

(guess) pause, dots indicate length

cut-off of the prior word or sound

underlining shows speaker emphasis

laughter without words

words between the $\$$ signs spoken in a laughing voice

transcriber guessed the word(s) 